\section{JOURNAL OF INFORMATION SYSTEM AND TECHNOLOGY MANAGEMENT (JISTM)}

WWW.jistm.com

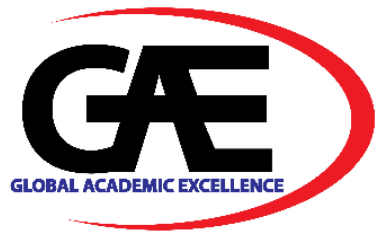

\title{
ISSUES AND CHALLENGES AMIDST THE PANDEMIC ERA: ENGLISH LEARNERS' VOICES
}

\author{
Suyansah Swanto ${ }^{1}$, Wardatul Akmam Din ${ }^{2 *}$, Iziana Hani Ismail ${ }^{3}$, Nur Anneliza Abd Latip ${ }^{4}$ \\ 1 Faculty of Psychology and Education, Universiti Malaysia Sabah, Malaysia \\ Email: suyansah@ums.edu.my \\ 2 Faculty of Psychology and Education, Universiti Malaysia Sabah, Malaysia \\ Email: wardadin@ums.edu.my \\ 3 Preparatory Centre for Science \& Technology, Universiti Malaysia Sabah, Malaysia \\ Email: iziana.hani@ums.edu.my \\ 4 Preparatory Centre for Science \& Technology, Universiti Malaysia Sabah, Malaysia \\ Email: nuranne@ums.edu.my \\ * Corresponding Author
}

\section{Article Info: \\ Article history: \\ Received date: 11.09 .2021 \\ Revised date: 10.10 .2021 \\ Accepted date: 15.11 .2021 \\ Published date: 30.11 .2021 \\ To cite this document: \\ Swanto, S., Din. W. A., Ismail, I. H., $\&$ Abd Latip, N. A. (2021). Issues and Challenges Amidst the Pandemic Era: English Learners' Voices. Journal of Information System and Technology Management, 6 (23), 72-80.}

DOI: $10.35631 / J I S T M .623006$

This work is licensed under $\underline{\text { C B BY 4.0 }}$ (1)(1)

\section{Abstract:}

Corona virus disease 2019 has become a current pandemic and many countries have been affected by it. At the end of January 2020, the WHO Emergency Committee declared a global health emergency state as COVID-19 confirmed cases have been increasing internationally. Since then, online learning has been actively implemented globally including Malaysia. This research is purely qualitative where data was collected via online interview with four willing secondary students. The findings highlight that there are a few weaknesses regarding online learning. Poor internet connection contributes to one of the weaknesses in online learning in Malaysia. Furthermore, not understanding teachers' teaching is also one of the limitations of online education. Online learning limitations might vary depending on the students' technological capability to access online sites and use computers. These limitations are more evident for young children or school-age students who may not have online access. Although online learning has its flaws however it comprises several strengths too. Online learning enables the students to have flexible time in participating in the lesson. Avoiding from the virus is the next advantage of conducting online learning. Although schools are closed however students still could get connected with their teachers through several devices like computers, laptops, tablets and mobile phones. Hence, online learning is deemed to be the best alternative to continue the learning process and at the same time protects young learners from this deadly virus. 


\section{Introduction}

First report of the COVID 19 (initially dubbed as Wuhan pneumonia) case was recorded in Wuhan City, China late December 2019. Since then, the virus had spread to other countries and established itself as a global threat. WHO announced COVID-19 outbreak as a pandemic on the 11th March 2020(Liu, Kuo and Shih, 2020). The world: a state of confusion and uncertainty. This pandemic - almost singlehandedly (literally) paralyzed the world's economy and community. The Corona virus (COVID-19) pandemic: an unprecedented crisis in all areas of society (including education worldwide).

The COVID-19 pandemic was dubbed as the largest disruption of education in history that impacted on learners and educators around the world, from pre-primary to secondary schools, technical and vocational education and training (TVET) institutions, universities, adult learning, and skills development establishments. In the field of education, to prevent the spread of the virus and mitigate its impact, massive closure of face-to-face activities at educational institutions in more than 200 countries (Congressional Research Service,2021) and the education systems around the world were rather swift to react and adapt.

To ensure education continuity and protect the safety of learners, educators as well as other education stakeholders, schools and other learning institutions were swiftly closed. During the time of educational institution closures, governments the world over made education continuity a priority. Many of them turned to ICT, instructing and mobilizing educators at all levels to move from face-to-face to online delivery of lessons (synchronous as well asynchronous).

Having said that it is important for all to realise that every cloud has a silver lining. They are:

- Stimulation of innovation within the education sector and accelerated changes in modes of delivering quality education.

- Innovative approaches in support of education and training continuity: radio, television, virtual classrooms and take-home packages etcetera.

- Distance learning solutions were developed in support of education continuity.

The traditional face-to-face teaching and learning has always been the gold standard of delivering lessons due to the many benefits it comes with. Face-to-face teaching and learning are dynamic, providing real-time face-to-face interaction, allow immediate feedback and teacher response, and a more flexible content delivery (Paul and Jefferson, 2019). For students, it gives them a valuable face-to-face interaction, pre- and post-class discussions, communal learning, and organic student-teacher bonding (Royal and Jordan, 2004). It also does not rely on a networked system, reducing the risk of technical problems and the cancellation of lessons due to unreliable Internet connection as well as providing more motivation, encouragement and direction. (Paul and Jefferson, 2019).

However, another modality of teaching and learning is gaining traction, which is face-to-face teaching and learning and this form of teaching is conducted in multiple ways: online learning, 
Volume 6 Issue 23 (November 2021) PP. $72-80$ DOI: 10.35631/JISTM.623006

Special Issue: Foundation Program Education Post-Covid-19: Issues and Opportunities web-based learning, synchronous learning, asynchronous learning, and many more. Non faceto-face teaching and learning allows students to learn anywhere and anytime, the luxury of courses/subject to choose and the freedom to learn at one's preferences (Wladis et. al, 2015).

\section{What Is The Problem?}

In Malaysia, most of the teaching and learning process is conducted through face-to-face interactions due to several restricting factors such as gadget ownership, location, and the quality of Internet connection just to list a few. The 2018 Internet Users Survey conducted by the Malaysian Communications and Multimedia Commission came to a discovery that there is a large disparity between urban and rural Internet users. Internet users in urban areas constitute $70 \%$ of the total Internet users (Malaysian Communications and Multimedia Commission, 2018).

ESL Educators plays a pivotal role: to ensure education continuity during the pandemic. From the onset of the pandemic, teachers were immediately tasked with implementing distance learning modalities, often without sufficient guidance, training, or resources. On the other side of the coin, students have also been "impacted, from balancing school and home responsibilities to the difficulties of finding a suitable space to participate in the online class as well as completing their assignments and exercises" (Bahar, et al. 2020).

Few research has been done to look into the issues and challenges faced by students in fulfilling their roles during the pandemic especially in this part of the world and to elicit their perspectives towards online teaching delivery amid corona virus pandemic.

There is a need listen to the English learners' voices - issues and challenges in dealing with teaching and learning during this difficult time. However, the question remains whether non face-to-face teaching and learning is as good or a better replacement to face-to-face teaching and learning in achieving the country's national curriculum aspirations. Are students benefiting the most from this form of teaching delivery?

\section{Methodology}

The study was carried out using a qualitative research approach. The study was carried out through case study. A case study is described as an intensive, systematic investigation of a single individual, group, community or some other unit in which the researcher examines indepth data relating to several variables (Heale \& Twycross, 2018). This approach is taken due to the number of participants in the study, where 4 secondary school students agreed to be interviewed. The study might focus on several participants. Hence, case study is chosen as an approach and interview data was collected. This is the best method when conducting this type of research. This is because the study aims to look upon the belief and perspective of the participants. The interview data was analysed using Thematic Analysis (Braun and Clarke, 2006) and SWOT analysis. The participants selected for the semi-structured interviews were four secondary school English language learners. In order to ensure trustworthiness, data was put through member checking for credibility.

SWOT Analysis is a tool used for strategic planning and strategic management in organizations that can be used effectively to build organizational strategy and competitive strategy (Dergisi, 2017). The method was used in order to determine the effectiveness of non-face to face teaching Copyright $\odot$ GLOBAL ACADEMIC EXCELLENCE (M) SDN BHD - All rights reserved 
Volume 6 Issue 23 (November 2021) PP. $72-80$ DOI: 10.35631/JISTM.623006

Special Issue: Foundation Program Education Post-Covid-19: Issues and Opportunities and learning. SWOT analysis was carried out based on the interview transcriptions in order to come up with the evaluation towards online learning during the pandemic crisis. The research allows for numerous ideas to emerge to cover the gaps in the SWOT (strengths, weaknesses, opportunities, and threats) sectors. All interviewees were subjected to a series of questions.

This study aims:

- To evaluate the effectiveness of non face-to-face teaching and learning in achieving the national ESL curriculum objectives.

- To discover the issues and challenges that hamper the successful implementation of non face-to-face teaching and learning at educational institutions.

- To explore the possible recommendations to improve non face-to-face teaching and learning in the future.

\section{Findings}

From the interview data, the findings can be categorised as these four issues:

\section{Strengths}

Although research have shown that non face-to-face teaching and learning appeals to students for many reasons, both students 1 and 2 did not have much to say about its advantages. Upon further inquiries, student 2 admitted that by having non face-to-face learning, she experienced a greater sense of flexibility. As learning takes place at home and at the place where she felt very comfortable, she felt relaxed, as she "did not have to worry about her uniform and adhere to the strict schedule at school". She was also able to choose her own time to do her homework and "refer to the materials from the teacher any time". Paul and Jefferson (2019) applaud the flexibility of non face-to-face teaching and learning for it affords students the opportunity to study from anywhere and at any time. It gives even greater flexibility for working adults who wish to receive a quality education without having to sacrifice work time and family time (Paul and Jefferson, 2019).

Student 3 cited that online learning permits her to have flexible time. Selvanathan, Hussin, \& Azazi (2020) likewise presented those students opted to have flexible time for learning, which is more convenient for them to access the teaching materials. Students don't have to rigidly follow the schedule that has been arranged for the physical class interaction. Shahida Naz, Memona Rasheed \& Tahir Rasheed (2019) correspondingly cited that with a growing number of portable, digital, Android, smart and intelligent devices it is possible to offer students the flexibility to acquire knowledge at their convenience, in any place and at any time. Based on the above statements, it is seen that online learning indeed offers students flexible time in acquiring knowledge.

Avoiding from the virus is the next advantage of conducting online learning. Student 3 remarked, "it is safer to stay at home during the Covid-19". Since the spread of this virus, distance education became omnipresent (Kim, 2020). The conduction of online classes is mandatory from the minister of education following the present COVID-19 pandemic crisis (Deepika, 2020). Due to the notion that mass gatherings have a greater risk during this pandemic, the decision to temporarily close the educational institutions was made by the government (Selvanathan, Hussin, \& Azazi, 2020). Although schools are closed however 


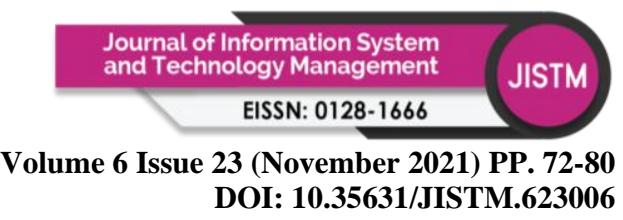

Special Issue: Foundation Program Education Post-Covid-19: Issues and Opportunities students still could get connected with their teachers through several devices like computers, laptops, tablets and mobile phones. Hence, online learning is deemed to be the best alternative to continue the learning process and at the same time protects young learners from this deadly virus.

\section{Weaknesses}

One weakness of non face-to-face teaching and learning that the students were passionately talking about was its reliance on technological tools or gadgets such as computers, mobile phones, and tablets. Although possessing their respective tools (student 1 share his mobile phone with his siblings and student 2 has a mobile phone and uses a home computer), they agreed that they spent so much time glued to the screens. Student 2 "would love to be in a classroom" and "not sitting in front of the computer for hours" as it is "tiring". For student 1 , the need to use his mobile phone for lessons left him with an unpleasant situation. He recalled the time when his younger brother demanded his phone to play games when he needed to attend an online class. He had no choice but to allow his younger brother to use his phone for a while, otherwise the younger brother would "cry all day long" and it is "boring" to him. Chong (2020) highlighted that the reliance on technological tool might come in the way of successful teaching and learning since not all students can afford one. Even if each student possesses one, there are other issues such as Internet connectivity and limited data plan.

Student 2 further added that with non face-to-face teaching and learning, scheduling a discussion with classmates became harder. In a traditional face-to-face lesson, they have time for discussion during the lesson allotted by the subject teacher. Even if they cannot finish their discussion, they can always continue after school. Now, it is not always the case although the Internet always connects people. Sometimes, the meeting she scheduled could not proceed when her classmates "forgot the planned meeting". Some even took "days to reply to her messages". This is contrary to the claim by Richardson and Swan (2003) that through online learning, students have the freedom to communicate with instructors, address classmates, study materials, and complete assignments from any internet access point. The probable explanation could be attributed to students' behaviour and commitment to their studies.

Student 3 also mentioned that he has a poor Internet connection at home. Hence, it is hard for him to attend online classes due to the unstable Internet connection. He also revealed that he doesn't want to attend any online courses, as it is hard for him to understand the lessons. Thus, he prefers face-to-face interaction. Student 3 mentioned the same point as him where she stated that face-to-face interaction allows her to ask questions directly and helps her in comprehending the lesson better. Based on their statements, it shows that they are probably not ready with the online learning style although this kind of learning has been practiced in Malaysia since the late 1990s. Lau and Shaikh (2012) also cited that computer and Internet effectiveness affecting the students' online learning readiness. Therefore, poor Internet connection contributes to one of the weaknesses in online learning in Malaysia.

Furthermore, not understanding teachers' teaching is also one of the limitations of online education. Student 4 stated that he was unable to comprehend the whole lesson because teachers conducted the lessons in a short time. He needs more guidance especially in the Chinese, English, Mathematics and Malay subjects. The hardest skill for him is the Chinese writing skill. Therefore, he needs teachers to be physically there with him. Student 4 uttered a Copyright $\odot$ GLOBAL ACADEMIC EXCELLENCE (M) SDN BHD - All rights reserved 


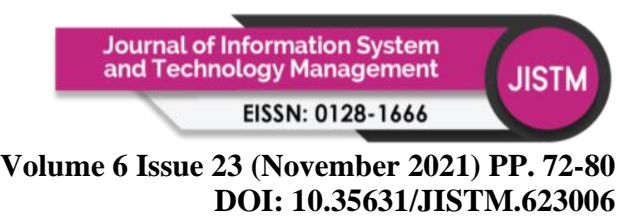

Special Issue: Foundation Program Education Post-Covid-19: Issues and Opportunities related point, she said that "from time to time, we need to have interactions to be able to ask questions. Can directly ask questions, not through WhatsApp or texting. Then, I will be able to understand better". By listening to their views, it assures me that they truly need guidance and physical interactions from teachers. Setting up face-to-face interaction provides students with direct feedback on the quality of teaching, delivery, and experience (Deepika, 2020). Students want teachers to conduct the lesson longer however teachers can't meet the needs of some pupils. Online learning limitations might vary depending on the instructors' or students' technological capability to access online sites and use computers. These limitations are more evident for young children or school-age students who may not have online access (Fedynich 2014; Wedenoja 2020). In a nutshell, online learning needs to take account of the children's developmental level so that students can learn and develop their learning (Kim, 2020). Therefore, not understanding teachers' teaching contributes to one of the weaknesses in online learning.

\section{Opportunities}

The interviews with both participants did not reveal much about the opportunities non face-toface teaching and learning promises despite a number of them revealed by several studies. Non face-to-face teaching and learning may make learning materials more accessible, learning more enticing and it leads to better class performance (Paul and Jefferson, 2019). The students expressed none of these. One opinion of student 2 might qualify as an opportunity non face-toface teaching and learning brings - the opportunity to learn other skills directly and indirectly.

Student 2 shared her success in writing e-mails properly as taught by her teacher. She also learnt how to use the poll feature on Telegram and other applications on Google Classroom. She was proud of her newfound skills and eager to show her parents that she could do many things on Google Classroom.

Through online learning, learners are also able to develop into hardworking learners. "Need to be hardworking and always do homework are the characteristics that we need to have for online education" was the statement given by Student 3. The above statement yields that online learning opens the path for learners to be diligent in their learning. This is probably due to the present situation that requires learners to work independently. Rudaleva, Kabasheva, \& Kovaleva (2016) indicated the identical idea that this form of education encourages learners to work independently. Thus, not only learners can develop a hardworking attitude it also allows learners to obtain learning opportunities amid during the pandemic (Fedynich 2014); Yilmaz 2019).

Self-motivated in learning is the other fact to put on in the opportunity section. Encouraging motivation to learn is one of the main principles for effective education (Kim \& W. Frick, 2011). Student 3 said, "Students need to be self-motivated in online education". This is an opportunity that students can gain in partaking in the online class. When learners have the motivation to learn, they will eventually have self-discipline. "We need to have our initiative to understand teacher's lessons" said Student 4 concerning self-discipline.

Selvanathan, Hussin, \& Azazi (2020) likewise conveyed those learners are motivated in this environment as it gives a sense of ownership and readership. Students will be more motivated 


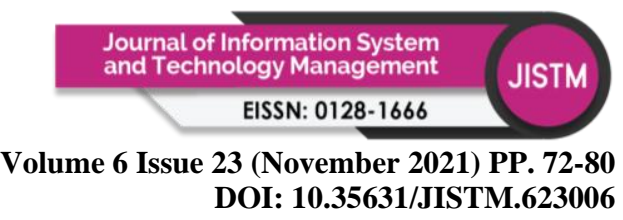

Special Issue: Foundation Program Education Post-Covid-19: Issues and Opportunities when e-learning is applied. If pupils are more driven to learn, then they are more likely to be engaged (Harandi, 2015).

\section{Threats}

Being a new practice in Malaysia specifically, non face-to-face teaching and learning success and sustainability are threatened by a few elements such as Internet coverage and speed (Chong, 2020) as well as the tendency for online learners to quit as a result of the lack of feedback to and from both educators and students (Atchley et al., 2013). One of them is students' incompetency to manage their time well. Staying at home all the time induces students to become inactive and spend less time studying. Both students admitted that they spent more time sleeping at home when they should spend their time studying. Student 1 professed that he regularly 'handed in his work later than the due date. He also spent a lot of time lying down on the bed even during his online class.

Student's lack of understanding might be a threat in conducting online learning. Student 4 mentioned that the lesson was conducted in a short time hence he didn't fully understand the lesson. Student 3 conveyed that she didn't understand the teacher's questions during online lessons. Technically, teachers perform online classes in accordance with what educators are urged by the Ministry of Education. Nonetheless, teachers might not able to administer to every student's inability to comprehend the lessons due to many uncontrollable factors such as student's technical difficulty, student's proficiency level and student's environment. Ferri, Grifoni, \& Guzzo (2020) further mentioned that although students are normally accustomed to the usage of digital devices, they may be unprepared to receive remote teaching, and it might be challenging to grab their attention. In addition, parents may lack the basic educational level and language proficiency in terms of digital skills. Based on the statement given, it shows that the uncontrollable factors that were previously mentioned could contribute to students' lack of understanding in online learning. Therefore based on the interview done with Student 1 and 2, students' lack of understanding could be the threats in online learning in Malaysia.

The students and their parents should treat such practices or behaviours appropriately. Failure to do so would render the non face-to-face teaching and learning ineffective regardless of the effort an educator put beforehand.

\section{Recommendation}

All the students felt that they were unsure whether the delivery of lessons through non face-toface learning has been a great help to their learning. Undeniably lessons have taken place and they tried to benefit from the lessons to the best of their abilities.

According to them, things would be better if the government could improve the Internet connection and provide free data to students. Student 2 did not struggle so much with Internet data since her parents subscribed to a broadband plan. Therefore, her recommendation would most probably be representative of her classmates who have problems with a limited Internet data plan. Student 1,3 and 4 on the other hand felt strongly about this matter. They always had problem with their Internet data running out faster than they expected. Students such as students 1,3 and 4 are at a disadvantage for being limited by their data plan, which disallow them to join online classes in real-time and increases the possibility of not being able to access learning materials as they wish. In the long run, they have a high risk of being left behind (Chong, 2020). Copyright $\odot$ GLOBAL ACADEMIC EXCELLENCE (M) SDN BHD - All rights reserved 


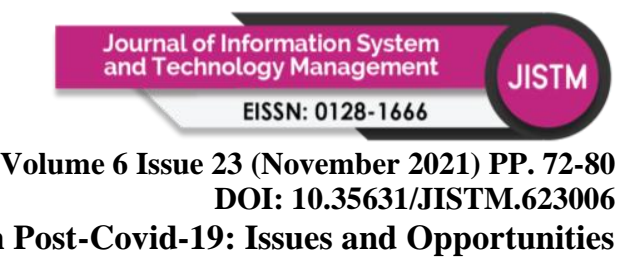

\section{Conclusion}

Non face-to-face teaching and learning evidently possesses some features that are constructive and beneficial in the right situation and for the right people. This study found that there are students who could not reap the benefit of non face-to-face teaching and learning to the fullest. Instead, it almost became a stumbling block to them. Therefore, it is safe to conclude that non face-to-face teaching and learning has a long way to achieve the national curriculum aspirations. In order to speed up the process, the government, government agencies and the private sector need to play proactive parts and play their roles.

\section{References}

Atchley, W., Wingenbach, G., \& Akers, C. (2013). Comparison of course completion and student performance through online and traditional courses. Int. Rev. Res. Open Dist. Learn. (14), 104-116. doi: 10.19173/irrodl.v14i4.1461

Azhari FA and Ming LC (2015) Review of e-learning practice at the tertiary education level in Malaysia. Indian Journal of Pharmaceutical Education and Research 49(4): 248-257.

Chong, P. Y. (2020, Jun, 1). Covid-19: Impact on The Tertiary Education Sector in Malaysia. Retrieved from https://penanginstitute.org/publications/covid-19 crisisassessments/covid-19-impact-on-the-tertiary-education-sector-in-malaysia/

Deepika, N. (2020). The impact of online learning during COVID-19: students' and teachers' perspective. The International Journal of Indian Psychology.

Dergisi, U. S. (2017). SWOT Analysis: A Theoretical Review. The Journal of International Social Research, 996-1005.

Fedynich, L. V. (2014). Teaching beyond the classroom walls: The pros and cons of cyber learning. Journal of Instructional Pedagogies, $13,1$. https://www.aabri.com/manuscripts/131701.pdf

Ferri, F., Grifoni, P., \& Guzzo, T. (2020). Online Learning and Emergency Remote Teaching: Opportunities and Challenges in Emergency Situations. Societies. https://doi.org/10.3390/soc10040086

Harandi, S. R. (2015). Effects of e-learning on Students' Motivation. Procedia - Social and Behavioral Sciences. https://doi.org/10.1016/j.sbspro.2015.04.905

Hussin H, Bunyarit F and Hussein R (2009) Instructional design and e-learning: examining learners' perspective in Malaysian institutions of higher learning. Campus-Wide Information System 26(1): 4-19.

Kim Kyong-Jee and W. Frick Theodore, (2011), Changes in Student Motivation during Online Learning, Journal of Educational Computing Research, Vol 44, Page(s) $1-23$

Kim, J. (2020). Learning and Teaching Online During Covid-19: Experiences of Student Teachers in an Early Childhood Education Practicum. International Journal of Early Childhood. https://doi.org/10.1007/s13158-020-00272-6

Lau CY and Shaikh JM (2012) The impacts of personal qualities on online learning readiness at Curtin Sarawak Malaysia (CSM). Educational Research and Reviews 7(20): 430444.

Lin, C. H., Zhang, Y., \& Zheng, B. (2017). The roles of learning strategies and motivation in online language learning: A structural equation modeling analysis. Computers and Education, 113, 75- 85.

Malaysian Communications and Multimedia Commission. 2018. Internet Users Survey 2018: Statistical Brief Number Twenty Three. Cyberjaya: Selangor Darul Ehsan

Copyright $\odot$ GLOBAL ACADEMIC EXCELLENCE (M) SDN BHD - All rights reserved 


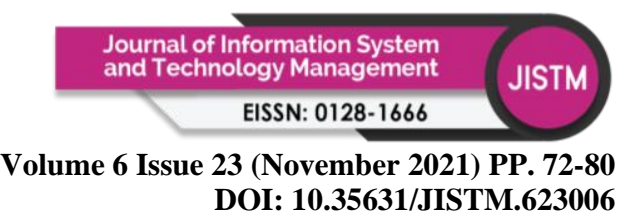

Special Issue: Foundation Program Education Post-Covid-19: Issues and Opportunities

McAleer, M. (2020). Prevention Is Better Than the Cure: Risk Management of COVID-19. Journal of Risk and Financial Management, 13(3). https://doi.org/10.3390/jrfm13030046

Ministry of Education Malaysia (MOE) (2015) Malaysia Education Blueprint 2015-2025 (higher education). Putrajaya: Author

Paul, J. \& Jefferson. F. (2019). A Comparative Analysis of Student Performance in an Online vs. Face-to-Face Environmental Science Course From 2009 to 2016. Frontiers in Computer Science, (1), 1-9. DOI=10.3389/fcomp.2019.00007

Richardson, J. C. \& Swan, K. (2003). Examining social presence in online courses in relation to student's perceived learning and satisfaction. J. Asynchr. Learn. 7, 68-88. DOI: http://dx.doi.org/10.24059/olj.v7i1.1864

Roval, A. P. \& Jordan, H. M. (2004). Blended learning and sense of community: a comparative analysis with traditional and fully online graduate courses. Int. Rev. Res. Open Dist. Learn, (5). doi: 10.19173/irrodl.v5i2.192

Rudaleva, I., Kabasheva, I., \& Kovaleva, E. (2016). The effectiveness of e-learning: Based on students' evaluation. SHS Web of Conferences. https://doi.org/10.1051/shsconf/20162601128.

Selvanathan, M., Hussin, N. A. M., \& Azazi, N. A. N. (2020). Students learning experiences during COVID-19: Work from home period in Malaysian Higher Learning Institutions. Teaching Public Administration. https://doi.org/10.1177/0144739420977900

Shahida Naz, Memona Rasheed \& Tahir Rasheed. (2019). The role of smartphones in learning English: A study of learners' perspectives. International Conference on Research in Humanities, London United Kingdom, 1(2)17-28.

Velavan, T. P., \& Meyer, C. G. (2020). The COVID-19 Epidemic. Tropical Medicine and International Health, 25(3), 278-280. ://doi.org/10.1111/tmi.13383

Wedenoja, L. (2020). What to expect when you weren't expecting online classes. Rockefeller Institute of Government. https://rockinst.org/blog/what-to-expect-when-youwerentexpecting-online-classes/

Wladis, C., Conway, K. M., \& Hachey, A. C. (2015). The online STEM classroom who succeeds? An exploration of the impact of ethnicity, gender, and nontraditional student characteristics in the community college context. Commun. Coll. Rev. (43), 142-164. doi: $10.1177 / 0091552115571729$.

Yilmaz, A. B. (2019). Distance and face-to-face students' perceptions towards distanceeducation: A comparative metaphorical study. Turkish Online Journal of DistanceEducation-TOJDE, 20(1), 1302-6488. https ://files .eric.ed.gov/fullt ext/EJ1201959.pdf. 